\title{
Corrigendum: Dose Dependent Antimicrobial Cellular Cytotoxicity-Implications for ex vivo Diagnostics
}

\author{
Ana Copaescu ${ }^{1 *}$, Phuti Choshi ${ }^{2}$, Sarah Pedretti ${ }^{3}$, Effie Mouhtouris ${ }^{1}$, Jonathan Peter ${ }^{2,3}$ and \\ Jason A. Trubiano ${ }^{1,4,5,6}$ \\ ${ }^{1}$ Centre for Antibiotic Allergy and Research, Department of Infectious Diseases, Austin Health, Heidelberg, VIC, Australia, \\ ${ }^{2}$ Division of Allergy and Clinical Immunology, Department of Medicine, University of Cape Town, Cape Town, South Africa, \\ ${ }^{3}$ Allergy and Immunology Unit, University of Cape Town Lung Institute, Cape Town, South Africa, ${ }^{4}$ Department of Oncology, \\ Sir Peter MacCallum Cancer Centre, The University of Melbourne, Parkville, VIC, Australia, ${ }^{5}$ Department of Medicine (Austin \\ Health), The University of Melbourne, Heidelberg, VIC, Australia, ${ }^{6}$ The National Centre for Infections in Cancer, Peter MacCallum \\ Cancer Centre, Melbourne, VIC, Australia
}

Keywords: delayed hypersensitivity reaction, drug allergy, severe cutaneous adverse reaction, t-cell, enzyme link immunospot, cytotoxicity, flow cytoametry, lactate dehydrogenase

\section{OPEN ACCESS}

Approved by:

Frontiers Editorial Office,

Frontiers Media SA, Switzerland

${ }^{*}$ Correspondence:

Ana Copaescu

ana.copaescu@gmail.com

Specialty section:

This article was submitted to

Translational Pharmacology,

a section of the journal

Frontiers in Pharmacology

Received: 13 August 2021

Accepted: 18 August 2021

Published: 02 September 2021

Citation:

Copaescu A, Choshi P, Pedretti S, Mouhtouris E, Peter J and Trubiano JA (2021) Corrigendum: Dose Dependent

Antimicrobial Cellular

Cytotoxicity - Implications for ex vivo Diagnostics.

Front. Pharmacol. 12:758192.

doi: 10.3389/fphar.2021.758192

\section{A Corrigendum on}

Dose Dependent Antimicrobial Cellular Cytotoxicity-Implications for ex vivo Diagnostics by Copaescu, A., Choshi, P., Pedretti, S., Mouhtouris, E., Peter, J., and Trubiano, J. A. (2021). Front. Pharmacol. 12:640012. doi: 10.3389/fphar.2021.640012

In the original article, we mistakenly omitted a statement from the Funding section. The statement reads as follows: "JP receives financial support from National Institutes of Health, award K43TW011178-02; the EDCTP2 programme supported by the European Union, grant number TMA2017SF-1981 and the South African National Research Foundation (NRF). PC receives a $\mathrm{PhD}$ fellowship from the Fogarty HATTP program, funded by the National Institutes of Health, award D43 TW010559-01".

The authors apologize for this error and state that this does not change the scientific conclusions of the article in any way. The original article has been updated.

Publisher's Note: All claims expressed in this article are solely those of the authors and do not necessarily represent those of their affiliated organizations, or those of the publisher, the editors and the reviewers. Any product that may be evaluated in this article, or claim that may be made by its manufacturer, is not guaranteed or endorsed by the publisher.

Copyright $\odot 2021$ Copaescu, Choshi, Pedretti, Mouhtouris, Peter and Trubiano. This is an open-access article distributed under the terms of the Creative Commons Attribution License (CC BY). The use, distribution or reproduction in other forums is permitted, provided the original author(s) and the copyright owner(s) are credited and that the original publication in this journal is cited, in accordance with accepted academic practice. No use, distribution or reproduction is permitted which does not comply with these terms. 